\title{
Toward a Framework for the
}

\section{Analysis of Rhodesian Politics}

This book examines the contemporary black-white cleavage in Rhodesia, a cleavage between a white minority with political power and an African majority with minimum political controls and influence at its disposal. While the main focus is on current politics, the first chapter reviews the emergence and development of racial attitudes from 1890 onward. Specifically, the question is asked why some Africans accepted the ground rules of the Rhodesian political system, including laws, elections, and parliamentary norms and rewards, while others went beyond prescribed limits and sought the destruction of the system.

Political opposition crystallizes in several different ways: It may operate strictly within a defined political system as constitutional opposition, or it may be anomic, seeking the spontaneous resolution of grievances. It may seek to modify, transform, or destroy a system from within, or it may operate from without, as extrasystem opposition. In Rhodesia, Africans have attempted all of these approaches in recent years, but as yet without success.

At first, the African nationalist movements participated in system politics; currently they engage in extrasystem conflict. The organizations of the 1920's and 1930's, such as the Rhodesian Native Association and the Rhodesian Bantu Voters' Association, operated within a constitutional framework. Subsequently the African National Congress 
(ANC) and the National Democratic Party (NDP) attempted to bring about radical but constitutional change within the system. But from the 1950's both the attitudes and actions of some nationalists were moving toward antisystem politics and then toward extrasystem conflict. Because of the intransigence of the white power structure, the Zimbabwe African People's Union (ZAPU) and Zimbabwe African National Union (ZANU) shifted from constitutional opposition to extrasystem political conflict-a qualitatively different political genre. From 1965 onward, however, other Africans participated in parliamentary opposition parties, such as the United People's Party, the National People's Union, and the Centre Party. These groups operated strictly within the political system of observed constitutional limitations.

The emergence of the African National Council in 1971 marked a temporary return to constitutional politics by some nationalist leaders (mainly from ZANU) in association with Africans within Rhodesia who were spontaneously responding to immediate and widespread fears that a settlement detrimental to their interests would be made between Great Britain and the Rhodesian Front government. At this time the return to a constitutional approach was precipitated by the British Pearce Commission's investigatory visit to Rhodesia, rather than by the nationalists' desire to compete within the existing political framework. The external presence of Great Britain, a responsible outside power attempting to divest itself of its responsibility but at the same time to protect both minority and majority interests, was once again a crucial variable in Rhodesian politics.

More precise distinctions may be drawn among political 
competition, political opposition, and opposition of principle. Political competition involves a challenge of personnel, for example, in-party disputes over leadership. Political opposition indicates a difference over policy goals but a willingness to operate within a system, as was the case with African parliamentary opposition parties. This category covers a wide range of parties, from those to the far right of the Rhodesian Front to liberal white opposition. On the other hand, opposition of principle is a challenge to the continued existence of the system itself, what Otto Kirchheimer calls the desire for a degree of goal displacement incompatible with the constitutional requirements of a given system. ${ }^{1}$

Opposition of the first two types operates within a highly institutionalized political system that defines the different legal means of competition. An opposition that realizes it has a reasonable chance to assume governmental responsibility is likely to operate within, and strongly support, the prevailing system. But in Rhodesia, constitutional provisions providing Africans with meaningful opportunities for assuming governmental responsibility have not existed. Thus it was never likely that nationalist-minded Africans would strongly support the system. Even when they were prepared to operate within it, accepting Giovanni Sartori's view that "an opposition must oppose but not obstruct; it must be constructive not disruptive," 2 the more articulate Africans ultimately stamped working within the system as a form of collaboration.

1 Otto Kirchheimer, "Germany, the Vanishing Opposition," in Political Opposition in Western Democracies, Robert Dahl, ed. (New Haven: Yale University Press, 1966), p. 237.

2 Giovanni Sartori, "Opposition and Control: Problems and Prospects," Government and Opposition, 1, no. 2 (Feb. 1966), 151. 
Some opposition groups, of course, diverge considerably from the traditional Western opposition models such as those of Britain and the United States, which center around an agreement to play fair (despite occasional aberrations) and acknowledge the rules of the parliamentary process as the permanent basis of the country's political life. ${ }^{3}$ Patterns and styles of opposition may vary from system to system, while uniform operational codes or rules of the game remain. On the other hand, "an opposition may represent interests . . . in a way that is hardly conducive to checking absolute power vis-à-vis minorities and dissenting opinions. . . . Its primary role may be confined to providing a channel of information which actually lacks, in the final analysis, effectiveness and efficacy; or it may only be a safety valve, a merely verbal outlet, in the sense that opposition is tolerated only to placate opposition." 4 But even where opposition is tolerated only to placate discontent, as has been the case in Rhodesia, it still operates within and sustains the system.

The term "party" usually implies the coexistence of different competing entities and the inclusion of these as parts in a political whole-something that never genuinely existed in Rhodesia. It has been said that "only where the specific interests of parties are embedded in a common whole does the political struggle not lead to disintegration of the entire group." 5 Thus a stable political system should be based on a field of commonality or of

3 See Silvano Tosi, "Italy: Anti-System Opposition within the System," Government and Opposition, 2, no. 1 (Nov. 1966), 49.

4 Sartori, "Opposition and Control," pp. 149-150.

5 Sigmund Neumann, Modern Political Parties: Approaches to Comparative Parties (Chicago: University of Chicago Press, 1965), p. $39^{6}$. 
consent on fundamentals. By its participation, a party actively creates conditions for its own survival and that of the system within which it operates. ${ }^{6}$ In Rhodesia, the African parliamentary opposition parties and the Rhodesian Front Party share a commonality or consent on fundamentals. They both participate in the system and support it, seeking to change it from within.

Ideally there are three separate entities in a parliamentary system. The first is the party-a team of men seeking to control the governing apparatus by gaining office in a duly constituted election. It has a unique history and a constellation of alternatives which it presents to the electorate. The party operates on several different levels: it seeks the selection of personnel, the formulation of public policies, the conducting or criticizing of government, political education, intervention between the individual and the government; representation, conversion, aggregation (i.e., compromise between competing points of view); integration (i.e., participation, socialization, and mobilization); persuasion, recruitment, and choice of leaders; policy formation; and control of government. The second entity is the opposition party (or parties), and the third is the political system in which both operate. While the requisites for constitutional politics include the existence of a shared political community (which transcends the issues over which the contestants battle) and a relatively stable and pluralistic balance between various social groups (with political resources to defend their interests), a form of con-

6 Roy C. Macridis, "Introduction: The History, Function, and Typology of Parties," in Political Parties, Contemporary Trends and Ideas, Roy C. Macridis, ed. (New York: Harper Torchbooks, 1967), p. 19 . 
flict is not excluded from the system. ${ }^{7}$ Indeed, the conflictintegration dialectic is central to an understanding of the operation of parties within a political system; conflict frequently helps to revitalize existent norms, or it contributes to the emergence of new norms. In this sense, social conflict is a mechanism for adjustment of norms to those adequate to new conditions. Clearly, then, an institutionalized form of conflict serves a constructive end by translating issues into objectives which can be achieved within the system.

In Rhodesia conflict of this type, leading to reaffirmation of the system or the integration of change, has primarily occurred within white politics. Since the Unilateral Declaration of Independence in 1965 , however, even this dimension has been limited. Opposition challenging the Rhodesian Front Party has been regarded as a threat to the viability of the system. On the other hand, the Rhodesian Front Party has attempted to integrate opposition to its right, or from the right wing within the party itself.

The question that now arises is why some conflicts may be categorized as institutionalized party conflicts operating through regularized channels, while others move out of this orbit, as has happened in Rhodesia. In order to understand this problem better, a distinction must be drawn between political opposition and political conflict: “Constitutional opposition presupposes 'quiet politics,' not turbulent politics. . . . Constitutional opposition belongs to a peaceful view of politics, not to a war-like approach in which the opposer is an enemy, an hostis." 8 The system,

7 See Lewis Coser, The Functions of Social Conflict (Glencoe, Ill.: Free Press, 1964), p. 154 .

8 Sartori, “Opposition and Control," p. 151. 
then, is one in which conflict serves a functional rather than a dysfunctional role and in which procedures exist for the management of conflict. It is one with channels for protest and scope for mobilization.

Political conflict, however, arises when such channels for pressure are seen to be inadequate or are believed to hamper particular objectives. At that point the issue becomes the extent or character of protest or conflict. Various factors affect the severity or intensity of political conflict: the composition of the groups engaged in the conflict, the readiness or reluctance of the incumbents of political power to broaden bases of support within that system, the scope of representation, the role of pressure groups, and the feasibility of alliances. In a plural society where the same persons are opponents on one occasion and allies on another, conflicts are likely to be less severe than in a situation where the lines are more permanently and rigidly drawn, as in Rhodesia. The severity of a conflict also depends on the way in which one conflict is related to another. ${ }^{9}$ It is possible for conflict to take place along different lines of cleavage-ideological, religious, ethnic, and so on. Where these factors reinforce each other, as in part they do in Rhodesia, the conflict tends to intensify. Conflicts may be further subdivided according to: scale-the degree of threatened disruption; scopethe size of the units involved; pervasiveness - the number and kinds of relationships disrupted; duration; and, finally, manifest expression-the specific overt activities involved.

Certain types of conflict may cut across society and unify different groups; for example, as we shall see, in a racial

9 See Robert A. Dahl, Pluralist Democracy in the United States (Chicago: Rand McNally, 1967), p. 271. 
conflict between white and black, some cross-cutting alignments may emerge as white groups join in common cause with Africans, although in Rhodesia the struggle is essentially a polarized one. Structurally, these groups may be united by commonly accepted definitions of their aims and the means by which these aims are to be achieved. In such groups, actions by members may convey specific meaning to other members, reflecting either irrelevance, assistance, or opposition. One of the primary aims may be group cohesion-the continued struggle with the outside may necessitate an intolerance of internal opposition.

A conflict involving high stakes frequently has no solutions other than the "mutually incompatible kind." ${ }^{10}$ Conflict may become revolutionary, where one class of people comes to believe that the only solution to their problem lies in the destruction of the prevailing system. When ideological differences are so sharp that a meeting point may never be possible, recognition by one of the groups of the fundamental irreconcilability of the division may be the only way to create basic change. African nationalists have increasingly moved in this direction. Although white liberals and some Africans working within the system have also explored the solution of coexistence, fundamental change by constitutional means-such as a move from a white minority political system to one that responds to majority interests-is remote. Evidence that a conflict is growing more severe would include harsher language, in which opponents are portrayed as implacable enemies to be annihilated; greater stress on actual employment of violence against opponents; and an increased resort to means

10 Ibid. 
that were previously regarded as illegitimate or unconstitutional. This latter criterion is an important one-the decision to move out of the context of a given system and into an uncharted area of extrasystem opposition with all of its implications of violence and revolutionary change. However sharp the initial distinctions between groups may have been, they may deepen as the out-group develops holistic ideological beliefs that attempt to rationalize and explain its actions. Creating such legitimacy is an important variable; before the hostile attitudes of the out-group, or negatively privileged group, can be turned into action, the group must develop the awareness that it is indeed negatively privileged. It must come to believe that it is being denied rights to which it is entitled. It must reject any justification for the existing distribution of rights, and privileges. ${ }^{11}$ The conflicting parties then no longer share the basic values or consensual bases of the system, and the result is "a struggle over values and claims to scarce status, power and resources in which the aims of the opponents are to neutralize, injure or eliminate their rivals." 12

Conflict situations may be resolved in different ways: by annihilation of one group, by total or partial compliance by one group based on the realization that continuation of the conflict would be futile, and, finally, by compromise or mutual concessions, a recognition that opposing forces are not always equal or complementary, nor are they always likely to become so. In any of these events, a relatively extensive and enduring reordering and redefining of the process of social organization is the end re-

11 Coser, Social Conflict, p. 137. 12 Ibid., p. 8. 
sult. If the balance of power is stable after an agreement, common norms might develop for the behavior of members of both groups. Possibly, however, only an uneasy compliance will result, with both sides prepared to resume the conflict. 


\section{RHODESIA}

Racial Conflict or

Coexistence? 
